\title{
An Examination of Price Discovery and Volatility Spillovers of Crude Oil in Globally Linked Commodity Markets
}

\author{
Sanjay Sehgal ${ }^{1}$, Neha Berlia ${ }^{2} \&$ Wasim Ahmad ${ }^{1}$ \\ ${ }^{1}$ Department of Financial Studies, University of Delhi, South Campus, New Delhi, India \\ ${ }^{2}$ Swiss Institute of Banking and Finance, University of St. Gallen, Switzerland \\ Correspondence: Neha Berlia, Swiss Institute of Banking and Finance, University of St. Gallen, 9000, \\ Switzerland. Tel: 41-71-222-0116. E-mail: neha.berlia@student.unisg.ch
}

Received: February 3, 2013

Accepted: March 15, 2013

Online Published: April 18, 2013

doi:10.5539/ijef.v5n5p15

URL: http://dx.doi.org/10.5539/ijef.v5n5p15

\begin{abstract}
This paper examines the price discovery and volatility spillovers between spot and futures as well as futures prices of three strategically linked oil markets viz., ICE, MCX and NYMEX from 05 February, 2006 to 15 October, 2012. The results confirm the long-run relationship between futures and spot prices in each market, futures prices lead spot prices in the price discovery process. Analysing the futures prices, we find that ICE is the most dominant futures trading platform followed by NYMEX and MCX in price discovery process. Thus, MCX an emerging market platform seems to act like a satellite market vis-à-vis international platforms. The volatility spillover results suggest that there is a long-term spillover from ICE to MCX and from MCX to NYMEX. The volatility information seems to flow from NYMEX to ICE. The GARCH-CCC \& DCC model results confirm both cross market and with in market co-movements which become weak during the crisis period and tend to become stronger during the stable period. The study provides relevant implications for policy makers and market traders. The outcome of this study contributes to commodity market literature especially relating to information transmission between strategically linked markets.
\end{abstract}

Keywords: price discovery, volatility spillovers, energy markets, crude oil market, MGARCH

\section{Introduction}

Since, the early 1970 s, the frequent upheavals in energy market especially the price of crude oil have always been an issue of great concern for academician, regulators and policy makers owing to its adverse impact on the macroeconomic fundamentals of the global economy. In this regard, an important issue that has garnered a great deal of attention of researchers and policy makers is of testing the efficient market behaviour of energy markets particularly the crude oil with respect to their price discovery and volatility spillover potentials (Lean, McAleer and Wong, 2010). In recent years, especially after the global economic crisis of 2008, there have been significant changes in the energy markets worldwide particularly the crude oil. In the literature, studies have considered several factors such as globalization, changing economic dynamics, international relations and global politics, war, technological innovations and developments in energy market and the recent financial crisis that has shifted the economic and political focus from west to east, as responsible for volatile energy market environment that has also increased the need of market players to hedge the investment risk using derivatives such as futures and options of energy products (Nomikos and Andriosopoulos, 2012). In international commodity market, crude oil market is characterized as an umbrella market because of large variety of products such as West Texas Intermediate (WTI); Brent Blend (BB); Maya, Bonny Light (BL) and Dubai-Fateh (DF). Among these crude oils, WTI and BB are considered as light and sweet crude oil because of higher API gravity index (Note 1) compared to others (Kaufmann and Ullman, 2009). Hence, WTI and BB are widely used for domestic and industrial purposes. In both mature and emerging markets, WTI and BB are also highly traded crude oil on their trading platforms. In terms of recent trends, WTI is being taken as a benchmark for price determination for crude oil industry. Keeping these issues in mind, this paper attempts to examine the price discovery and volatility spillovers between futures and spot prices and between futures prices of WTI traded on three commodity trading platforms viz., New York Mercantile Exchange (NYMEX), Inter-Continental Exchange (ICE) and Multi Commodity Exchange (MCX). It may be noted that NYMEX and ICE are two principle platforms for oil trading at global level, and hence compete with each other for price leadership role in crude oil market (Goyal and 
Tripathi, 2012). MCX is the major commodity exchange in India. India is a fast emerging trillion dollar economy for which crude oil is an important item in the import bill (Chakrabarty and Chakravarty, 2012). Hence, MCX in our case represents an emerging market platform which shall help us in understanding the information transmission process between mature and emerging economies relating to an international commodity like crude oil. In futures markets, a market is characterized as dominant market when it assimilates all the new information more quickly in its price and has stronger volatility spillovers to other markets (Hong, 2001). Under efficient market hypothesis $(\mathrm{EMH})$, it is assumed that all the publicly available information must be incorporated into the price of traded assets and no one should have lead in making speculation and arbitrage, but in a technology driven complex financial system, it is often observed that the process of information transmission is not as symmetrical as it is understood (Tangerås, 2012). Therefore, this motivates the researchers and policy makers to investigate the energy market platforms with respect to their price discovery and volatility spillover potential. In literature, price discovery implies the lead-lag relationship between futures and spot prices in a market and between futures prices in two different markets (Tse,1999). Under cointegration framework, it implies the establishment of long-run equilibrium relationship. In the event of any departures from equilibrium due to exogenous shocks, price discovery also takes into account the speed of adjustment of a market towards equilibrium price. Econometrically, such process is called as error correction mechanism (see, Zhong, Darrat, and Otero, 2004; Rittler, 2012). Besides, price discovery, volatility spillover also plays important role in information transmission as it highlights the process through which volatility in one market affects that of another market (Chan, Chan and Karolyi, 1991). The present study is particularly important in light of the increasing integration of global commodity markets that has generated interests for understanding the volatility spillovers from one market to another. These spillovers are usually attributed to the cross-market hedging and changes in commonly available information, which may simultaneously impact the expectations of various participants across markets (Engle, Ito and Lin, 1990). More specifically, volatility spillover examines information assimilation in two different ways: firstly, in terms of own-volatility spillovers under lagged innovations (information) and lagged volatility spillover effects, as it highlights whether lagged information and lagged volatility of an asset traded on an exchange impacts current volatility or not, if this is the case, it is called clustering effects under ARCH framework and volatility persistence under GARCH framework, it has strong implications for market participants as it highlights the assimilation of information other than the information contained in the price (Hong, 2001; Gagnon and Karolyi, 2006; Nekhili and Naeem, 2009). Secondly, cross-volatility spillovers measure spillover of past information and lagged volatility of an asset/market on other asset/market (Gagnon and Karolyi, 2006). It has also practical implications more importantly than the first one as it helps in characterizing the commodity market as dominant or satellite trading platform (see, Karmakar, 2009; Mahalik, Acharya and Babu, 2010; Du, Yu and Hayes, 2011; Liu and An, 2011; Arouria, Jouini, and Khuong, 2012, among others).

This paper also sets to examine the process of how volatility in the oil futures prices changes across markets. Since, oil prices in examined countries play important role in driving economic growth and among sample commodity exchanges, it is important for market participants to understand the volatility spillovers process across these exchanges and their dominance in oil trading. In particular, the study empirically examines the first and second moments properties of oil futures traded on three sample exchanges. Much of the research to date has focused on the interaction between the cash and the futures tiers of the crude oil market. The present study tries to answer the following research questions: Firstly, which is the dominant trading platform for crude oil trading (WTI) globally by comparing the information linkages between NYMEX and ICE, the two leading international trading platforms for oil futures contracts? Secondly, what is the information transmission process between these mature trading platforms and an emerging market trading platform such as MCX? In order to address these questions, the study sets to examine the following objectives:

(i) to examine the lead-lag relationship between spot and futures prices and between futures prices of sample markets;

(ii) to investigate the volatility spillovers among sample markets in order to ascertain the dominant and satellite platforms.

\section{Literature Review}

In this section, we mainly focus on the subject of information linkages among strategically located crude oil markets where research has been restricted to the financial markets, prior research has focused mainly on financial market and comparatively less attention has paid to the commodity and foreign exchange markets (see Koutmos and Booth, 1995; Hamao, Masulis, and Ng, 1990; Hong, 2001). Notable studies relating to energy products (see Antoniou and Foster, 1992; Ng and Pirrong, 1996; Tse and Booth, 1997; Lin and Tamvakis, 2001; 
Ewing, Malik and Ozfidan 2002; Hammoudeh, Li and Jeon, 2003; Lanza, Manera and McAleer, 2006; Malik and Hammoudeh, 2007; Mu, 2007; Hammoudeh and Yuan, 2008; Kaufmann and Ullman, 2009; Bekiros and Diks, 2008; Nomikos and Andriosopoulos, 2012; Arouri, Jouini, and Khuong, 2012; Ji and Fan, 2012). So far, none of the study has examined the price discovery and volatility spillovers by taking into account the recent changes in international economic dynamics and strong upheavals in energy products particularly the crude oil.

The study of Tse and Booth (1997) examines the information transmission between New York heating oil futures and London gas oil futures and reports that the former is more dominant market than later. The findings of their study imply that the information share can also determine the nature of the market. Lin and Tamvakis (2001) examine the spillover effects between NYMEX and London's International Petroleum Exchange (IPE) crude oil futures markets for the period 4 January, 1994 to 30 June, 1997. Broadly, the study reports that there is stronger volatility spillover from NYMEX to IPE when traded in different hours. Using Dynamic Conditional Correlations (DCC - GARCH), Lanza, Manera, and McAleer (2006) examine the daily returns on West Texas Intermediate (WTI) oil forward and futures prices for the period 3 January, 1985 to 16 January, 2004. The study finds the evidence of dramatic aberrations in time-varying conditional correlations with the magnitude being negative to zero. They further report strong variaitions in correlation patterns which is in contrast with the common view that usually suggests high correlation between futures prices of different maturit Spargoli and Zagaglia (2007) examine the comovement between futures markets for crude oil traded on NYMEX and ICE for the period 26 April, 1993 to 26 April, 2007. Using structural BEKK-GARCH model, the study reports that during the turmoil period, NYMEX reacts on the arrival of new information more quicker than ICE. This further implies that NYMEX assimilates new price related information quicker than ICE. Bekiros and Diks (2008) examine relationship between futures and spot prices of WTI under different time intervals by aplying the linear and nonlinear causal relationships for the period October, 1991 to October 2007. The study analyses two sample periods namely PI which spans (1991 to 1999) and PII (1999 to 2007). More importantly, the study highlights the weaknesses related with the first moment relationship (lead-lag relationship) with the use of nonlinear causality test. Based on the linear cauality results, the study finds bi-directional Granger causality between spot and futures prices in both periods, whereas the nonlinear causality results suggest the uni-directional causal relationship from spot to futures prices only in PII. Kaufmann and Ullman (2009) examine the unified nature of global oil market by way of investigating the causal relationships among prices for crude oils from Africa, Europe, Middle East and North America on both spot and futures markets. The study also includes different variants of crude oil such as WTI, BB, Maya, Bonny Light, Dubai-Fateh. The study reports the weak relationship between futures and spot prices. The study also finds that spot prices of Dubai-Fateh lead the other spot and futures prices, while among other crude oil futures and spot prices, WTI leads other exchanges and contracts. However, studies have also examined the information transmission of oil under different dimensions by linking the oil with metals and stock markets. In this regard, Lean, McAleer, and Wong (2010) examine the market efficiency of oil futures and spot prices prices of WTI by applying both mean-variance (MV) and stochastic dominance (SD) approaches. The study reports no evidence of any MV and SD relationships between examined series. The study also concludes that spot and futures donot dominate one another. Hence, there is no arbitrage opportunity between futures and spot markets.

More recently, Arouria, Jouini and Khuong (2012) examine the impact of oil price fluctuations on European equity markets by analysing the volatility spillover and hedging effectiveness. Based on the results of Vector Autoregression (VAR-GARCH) model, they find strong evidence of significant volatility spillovers between oil price and sector stock returns. Their findings imply that the volatility in the oil futures impacts the sector stock returns considerably. This further means that there is stronger flow of information from oil futures to sector stock returns. In Indian context, Goyal and Tripathi (2012) exmine the lead-lag relationship between spot and futures of crude oil by applying mutual and across exchange causality tests. Using the daily data of US WTI crude oil spot prices, UK Brent spot, MCX WTI spot, the study finds the evidence of price discovery in mature exchnages, where spot prices lead futures prices under VECM framework. The study further reports the reverse causality from emerging to mature exchnages. Ewing and Malik (2013) examine the volatility tranmission between gold and oil futures by taking into account the strcutural breaks. Using univarate and bi-variate GARCH models, the study finds the strong evidence of significant volatility transmission between gold and oil returns after taking into account the structural breaks in variance. By and large the findings of recent studies as mentioned above are not in line with the present work. To summarize, we can say that while there is a broad consensus on the role of information linkages across markets, the issue is still unsettled especially in the light of the recent turbulent periods which have jolted the commodity markets across globe especially the crude oil prices taking northward trend. Moreover, the futures markets in emerging countries are characterized by low liquidity and less efficient trading systems (Tomek, 1980; Carter, 1989), making them different from the counterpart markets in mature 
countries. Under emerging market framework, this is the first attempt to examine the price discovery and volatility spillovers by taking into account more recent period, which has still been unexplored in cross-market framework, is of great importance as it is the time when these trading platforms have achieved a higher level of trading liquidity and there may be strengthening of international linkages in terms of energy products.

\section{Methodology}

\subsection{Process of Price Discovery and Cointegration}

At first stage, stationarity condition using conventional methods of unit root tests viz., Augmented Dickey Fuller (ADF), Phillips and Perron (PP) and Kwiatkowski-Phillips-Schmidt-Shin (KPSS) tests have been used to check for stationarity for all sample series. Following Zhong, Darrat and Otero (2004) and Hou and Li (2012), we apply Johansen and Juselius (1992) test to exhibit the long-run relationship followed by vector error correction model (VECM) as mentioned in equations (1) and (2). The bivariate co-integrated series $P_{t}=\left(F_{t}, S_{t}\right)^{\prime}$, :

$$
\begin{gathered}
\Delta F_{t}=\alpha_{1}+\beta_{1} E C_{t-1}+\sum_{i=1}^{k} d_{1 i} \Delta F_{t-i}+\sum_{i=1}^{k} g_{1 i} \Delta S_{t-i}+\varepsilon_{1 t} \\
\Delta S_{t}=\alpha_{2}+\beta_{2} E C_{t-1}+\sum_{i=1}^{k} d_{2 i} \Delta F_{t-i}+\sum_{i=1}^{k} g_{2 i} \Delta S_{t-i}+\varepsilon_{2 t}
\end{gathered}
$$

Note that $E C_{t-1}=F_{t-1}-a-b S_{t-1}$ is the lagged error correction (EC) term.

The error correction model of the bivariate co-integrated series $P_{t}=\left(F_{1, t}, F_{2, t}\right)^{\prime}$, is represented by a vector error correction model (VECM):

$$
\begin{gathered}
\Delta F_{1, t}=b_{1}+\beta_{1} E C_{t-1}+\sum_{i=1}^{k} d_{1 i} \Delta F_{1, t-i}+\sum_{i=1}^{k} g_{1 i} \Delta F_{2, t-i}+\varepsilon_{1 t} \\
\Delta F_{2, t}=b_{2}+\beta_{2} E C_{t-1}+\sum_{i=1}^{k} d_{2 i} \Delta F_{1, t-i}+\sum_{i=1}^{k} g_{2 i} \Delta F_{2, t-i}+\varepsilon_{2 t}
\end{gathered}
$$

Where, $E C_{t-1}=F_{1, t-1}-a-b F_{2, t-1}$ is the lagged EC term.

Given the large number of parameters that would have to be estimated in the spillover model (discussed in subsection in 3.2), a two-step procedure similar to that implemented by Bekaert and Harvey (1997), Tse (1999), $\mathrm{Ng}$ (2000) and Rittler (2012) has been considered in this study. In the first step, a VECM is estimated to obtain the residuals. In the second step, first stage residuals are used to estimate the volatility spillovers between spot and futures prices and between the futures prices of both markets.

\subsection{Process of Volatility Spillovers}

Numerous studies have investigated the process of volatility spillover to exhibit the spread of news from one market that affects the volatility spillover process of another market. Considering the volatility spillovers across markets, the important studies in the existing literature are of Hamao, Masulis and Ng (1990), Koutmos and Booth (1995) and Lin, Engle and Ito (1994) for US, UK and Japanese Stock markets and Booth, Martikainen and Tse (1997) and Christofi and Pericli (1999) in other international stock markets. Most studies in the literature have used different variants of GARCH models to study the volatility spillovers between markets. Engle, Ito and Lin (1990) introduced the GARCH models to examine the volatility spillovers. According to Chan, Chan and Karolyi (1991), it is the volatility which determines the flow of information from one market to another and not just the simple price change. (Note 2)

Keeping in view the above mentioned literature, we now set up a model on the basis of the standardized residuals obtained from the VECM. The GARCH-BEKK (Baba, Engle, Kraft and Kroner, 1990) model is used to model the volatility spillover dynamics between futures and spot prices and between futures prices of ICE, MCX and NYMEX. Apart from BEKK model, constant conditional correlation (CCC) and dynamic conditional correlation (DCC) models are employed to infer upon the constant and time-varying correlation patterns of sample oil price series under consideration. A brief description of each model is mentioned below.

\subsubsection{GARCH (BEKK) Model}

The BEKK model is the most natural way to deal with the multivariate matrix operations. In this study, the model is implemented on the residuals of the series under following specification. 
Mean equation:

$$
v_{i t}=\mu_{i 0}+\sum_{j=1}^{2} \mu_{i j} v_{j, t-1}+\varepsilon_{i t}
$$

where $\varepsilon_{i t} \mid I_{i t-1} \sim N\left(0, h_{i t}\right), i=1,2$

In equation $5, v_{i t}$ is the estimated residual of the sample series. $\varepsilon_{i t}$ is a random error term with conditional variance $h_{i t} . I_{i t-1}$ denotes the market information at time $t$-1. Equation (5) specifies the variance equation. $i=1$, 2 denotes the bivariate model. The BEKK parameterization of multivariate GARCH model is written in the following manner:

$$
H_{t+1}=C^{\prime} C+A^{\prime} \varepsilon_{t} \varepsilon_{t}{ }^{\prime} A+B^{\prime} H_{t} B
$$

Where the individual elements of $\mathrm{C}, \mathrm{A}$ and $\mathrm{B}$ matrices for equation (6) are mentioned below:

$$
A=\left[\begin{array}{ll}
a_{11} & a_{12} \\
a_{21} & a_{22}
\end{array}\right], \quad B=\left[\begin{array}{ll}
b_{11} & b_{12} \\
b_{21} & b_{22}
\end{array}\right] \text { and } \quad C=\left[\begin{array}{ll}
c_{11} & 0 \\
c_{21} & c_{22}
\end{array}\right]
$$

The off-diagonal elements of matrix A ( $a_{12}$ and $a_{21}$ ) represent the short-term volatility spillover (ARCH effect) from market 1 to another market 2. The off-diagonal elements of matrix $\mathrm{B}\left(b_{12}\right.$ and $\left.b_{21}\right)$ represent the long-term volatility spillover (GARCH effect) in the same manner as mentioned above.

\subsubsection{CCC and DCC-GARCH Models}

Engle (2002) dynamic conditional correlation (DCC) model is estimated in two steps. In the first step, GARCH parameters are estimated followed by correlations in the second step.

$$
H_{t}=D_{t} R_{t} D_{t}
$$

In equation (7), $H_{t}$ is the $2 \times 2$ conditional covariance matrix as in our case, $R_{t}$ is the conditional correlation matrix and $D_{t}$ is a diagonal matrix with time-varying standard deviations on the diagonal.

$$
\begin{gathered}
D_{t}=\operatorname{diag}\left(h_{11 t}{ }^{1 / 2}, h_{22 t}{ }^{1 / 2}\right) \\
R_{t}=\operatorname{diag}\left(q_{11 t}{ }^{-1 / 2}, q_{22 t}{ }^{-1 / 2}\right) Q_{t} \operatorname{diag}\left({q_{11 t}}^{-1 / 2}, q_{22 t}{ }^{-1 / 2}\right)
\end{gathered}
$$

Where $Q_{t}$ is a symmetric positive definite matrix:

$$
Q_{t}=\left(1-\theta_{1}-\theta_{2}\right) \bar{Q}+\theta_{1} \varepsilon_{t-1} \varepsilon_{t-1}^{\prime}+\theta_{2} Q_{t-1}
$$

$\bar{Q}$ is the $2 \times 2$ unconditional correlation matrix of the standardized residuals $\varepsilon_{i t}$. The parameters $\theta_{1}$ and $\theta_{2}$ are non-negative with a sum of less than unity. Under the condition of $R_{t}=R$ and $R_{i j}=\rho_{i j}$ equation (9) becomes constant conditional correlation (CCC) model.

$$
\rho_{i j, t}=\frac{q_{i j, t}}{\sqrt{q_{i i, t} q_{j j, t}}}
$$

The MGARCH models are estimated by Quasi-Maximum Likelihood Estimation (QMLE) using the Broyden-Fletcher-Goldfarb-Shanno (BFGS) algorithm. T statistics are calculated using a robust estimate of the covariance matrix (see Sadorsky, 2012).

\section{Data}

The sample data for the daily spot and futures prices of NYMEX, ICE and MCX for WTI have been retrieved from the Bloomberg database. All closing prices of futures series are taken for the nearest contract to maturity (see Zhong, Darrat and Otero, 2004). The sample period of the study is 05 February, 2006 to 15 October, 2012 (1727 observations). In order to maintain parity across the sample markets, the price series are taken in USD terms (Note 3). For estimation purpose, all price series have further been converted into natural logarithms. The sample series under investigation are denoted as follows: ICE, NYMEX and MCX denote the futures prices of WTI crude oil traded on ICE, NYMEX and MCX platforms, MCXSPOT denotes the spot price of MCX and SPOT denotes the spot prices of ICE and NYMEX. 


\section{Empirical Results}

The time-series graphs of actual WTI crude oil prices clearly exhibit the evidence of similar movement in prices, implying that there is not much scope of arbitration in oil market and the relevant market information is intercepted by each sample market immediately (see Figure 1).
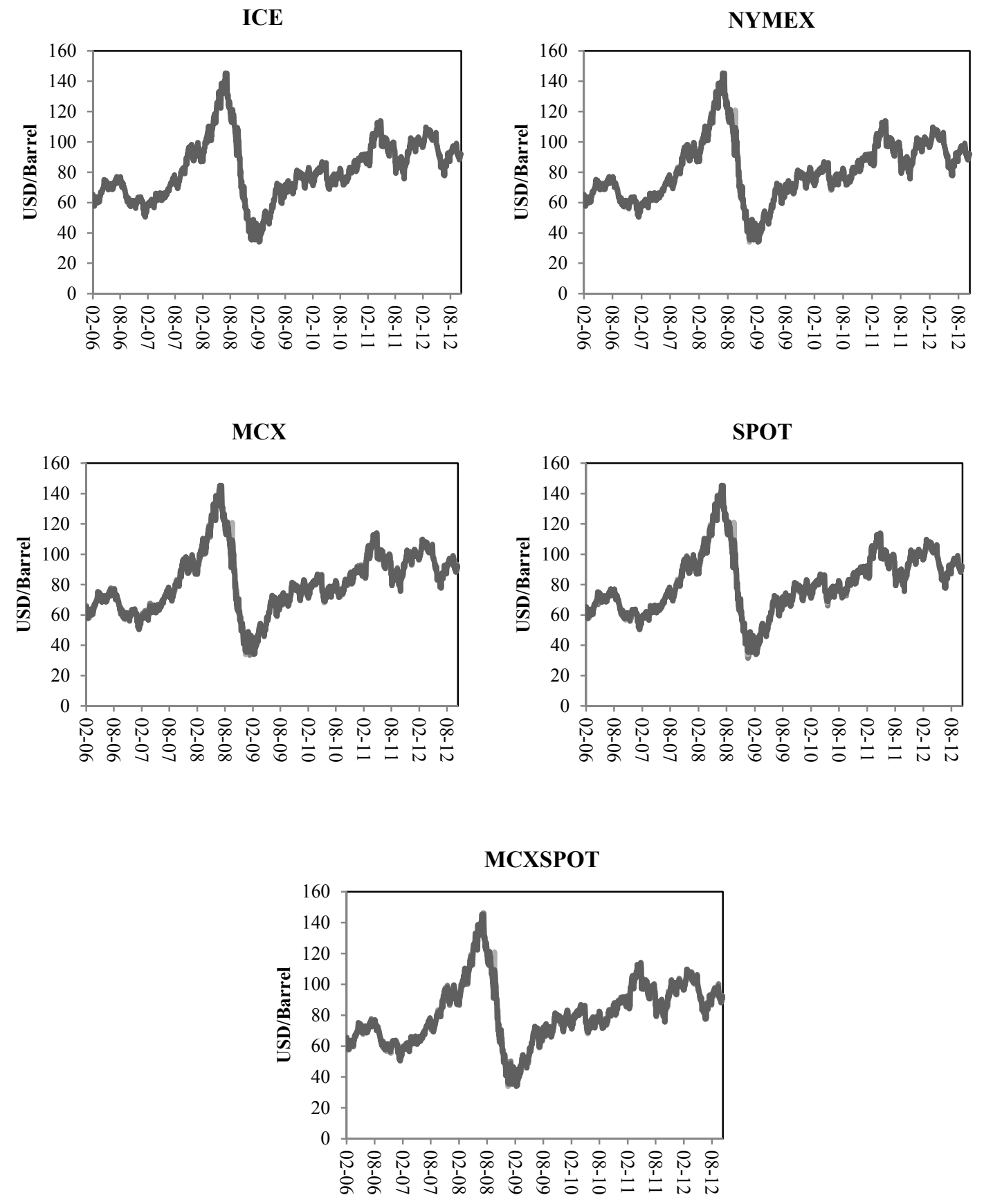

Figure 1. Time-series plots of ICE, NYMEX, MCX, SPOT and MCXSPOT 

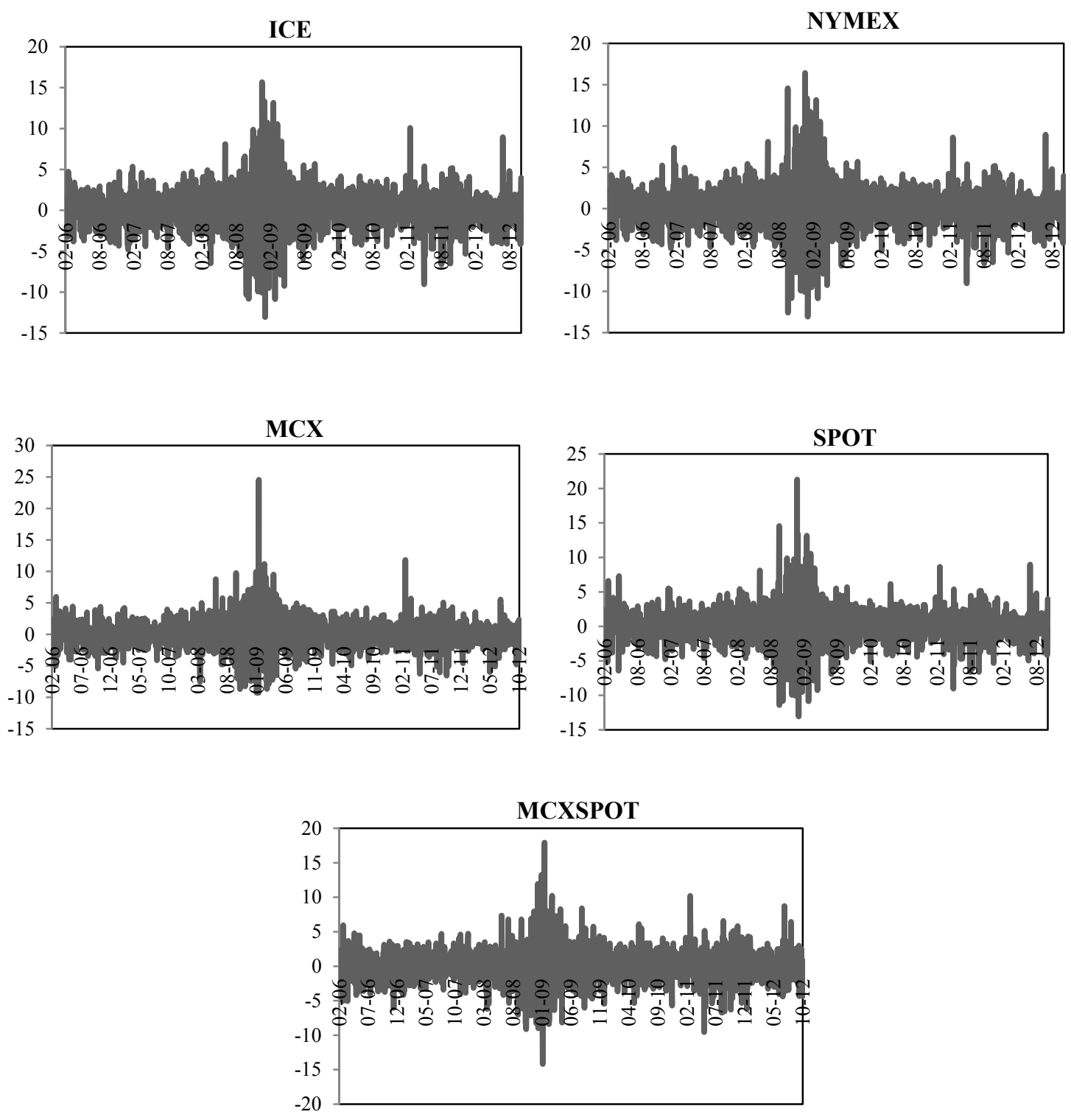

Figure 2. Time-series plot of daily returns of ICE, NYMEX, SPOT, MCX and MCXSPOT

Besides this, we have also plotted the continuously compounded daily returns graphs of all sample markets. It appears that there is strong case of clustering in each market during June, 2008 to August 2009 and during April, 2011 to June, 2011 (see Figure 2). While the first clustering period can be identified with the global economic crisis and its aftermath, second clustering period is linked with the phase when the Eurozone crisis intensified. The return behaviour of each market appears to be similar as it has been observed in case of actual prices. But it would be interesting to see how the behaviour of these markets changes in terms of their price discovery under first moment condition and volatility spillover in second moments. The descriptive statistics of sample oil futures and spot series as shown in Table 1 (Note 4). The mean returns of WTI crude oil appear to be almost same across markets. The highest mean daily returns are observed in case of NYMEX and SPOT which is 0.021 percent and lowest in case of ICE, MCX and MCXSPOT which is 0.020 percent. The standard deviation as a measure of volatility is highest for SPOT (2.559) and NYMEX (2.538) followed by ICE (2.477) and MCXSPOT (2.437). Strikingly, the lowest volatile market appears to be MCX which has volatility of 2.252 . However, this low volatility may be the outcome of lower information flows owing to less trading volume coupled with relatively greater price regulations in an emerging market like India. In general, the risk-returns relationship is positive for all sample series under consideration. The volatility measures are more than hundred times larger than the mean values. All returns series exhibit positive skewness and are also leptokurtic. This automatically leads to the violation of normality assumption as exhibited by Jarque-Bera (JB) statistics. The results imply that all the 
sample markets are not informationally efficient. There is also strong evidence of volatility clustering in sample series, indicating the need for greater analysis of second moment. Ljung-Box (LB) test confirms no autocorrelation in level of sample series up to 10 lags with the exception of NYMEX, MCX-SX and SPOT, while, all variables indicate significant autocorrelation in squared terms.

Table 1. Descriptive statistics of sample commodities

\begin{tabular}{llllll}
\hline & Futures Returns & & \multicolumn{3}{l}{ Spot Returns } \\
\hline & ICE & MCX & NYMEX & MCXSPOT & SPOT \\
\hline Mean & 0.020 & 0.020 & 0.021 & 0.020 & 0.021 \\
Max. & 15.659 & 24.532 & 16.410 & 17.915 & 21.277 \\
Min. & -13.065 & -9.301 & -13.065 & -14.196 & -13.065 \\
Std.Dev. & 2.477 & 2.252 & 2.538 & 2.437 & 2.559 \\
Skewness & 0.063 & 0.725 & 0.134 & 0.172 & 0.307 \\
Kurtosis & 7.453 & 13.421 & 7.972 & 7.346 & 9.308 \\
JB & 1427.781 & 7965.404 & 1783.879 & 1367.761 & 2890.642 \\
Prob. & {$[0.000]$} & {$[0.000]$} & {$[0.000]$} & {$[0.000]$} & {$[0.000]$} \\
Arch & 48.814 & 14.955 & 45.048 & $33.858[0.000]^{* *}$ & 57.608 \\
& {$[0.000]^{* *}$} & {$[0.000]^{* *}$} & {$[0.000]^{* *}$} & & {$[0.000]^{* *}$} \\
LB & $17.459[0.064]$ & $11.928[0.289]$ & 24.554 & 29.0469 & 30.376 \\
& & & {$[0.006]^{* *}$} & {$[0.001]^{* *}$} & {$[0.000]^{* *}$} \\
LB & 1106.96 & 239.081 & 1038.05 & 587.742 & 798.412 \\
& {$[0.000]^{* *}$} & {$[0.000]^{* *}$} & {$[0.000]^{* *}$} & {$[0.000]^{* *}$} & {$[0.000]^{* *}$} \\
Obs. & 1727 & 1727 & 1727 & 1727 & 1727 \\
\hline
\end{tabular}

Notes: ** denotes level of significance at $1 \%$ and better. Values in parentheses [ ] indicate the p-values. JB=Jarque Bera and LB= Ljung Box. LB statistics is reported up to 10 lags.

\subsection{Tests of Stationarity and Price Discovery Process}

Stationarity conditions of the oil futures-spot price series expressed in logarithmic form are tested by conventional ADF, PP and KPSS tests (see Table 2). All unit root tests clearly confirm the existence of unit root at level and exhibit stationarity at first difference for all oil price series. The results of Johansen and Juselius (1992) test of cointegration indicate that all sample oil price series exhibit the long-run relationship, confirming the strong informational linkages between spot and futures as well as between futures prices of the examined sample trading platforms (Table, 3). (Note 5)

Table 2. Unit root results

\begin{tabular}{|c|c|c|c|c|c|c|}
\hline & ADF & & PP & & KPSS & \\
\hline Variables & Level & First Difference & Level & First Difference & Level & First Difference \\
\hline \multicolumn{7}{|c|}{ Futures prices } \\
\hline ICE & -2.213 & $-43.971 * *$ & -2.061 & $-44.082 * *$ & 0.202 & $0.060 * *$ \\
\hline MCX & -2.045 & $-41.899 * *$ & -2.029 & $-41.900 * *$ & 0.204 & $0.061^{* *}$ \\
\hline NYMEX & -2.259 & $-43.947 * *$ & -2.088 & $-44.110^{* *}$ & 0.201 & $0.060^{* *}$ \\
\hline \multicolumn{7}{|l|}{ Spot prices } \\
\hline MCXSPOT & -2.181 & $-44.173 * *$ & -2.047 & $-44.252 * *$ & 0.202 & 0.061 \\
\hline SPOT & -2.258 & $-43.496 * *$ & -2.213 & $-43.503 * *$ & 0.201 & 0.055 \\
\hline \multicolumn{7}{|c|}{ Critical Values } \\
\hline $1 \%$ & -3.963 & & & & 0.216 & \\
\hline $5 \%$ & -3.412 & & & & 0.146 & \\
\hline $10 \%$ & -3.128 & & & & 0.119 & \\
\hline
\end{tabular}

Note: * indicates the level of significance at $1 \%$ and better.

Table 4 exhibits the VECM results. The EC which is also called as speed of adjustment co-efficient $\beta i$ is shown in the table. The results indicate that in case of between spot and futures prices of all sample markets, the speed of adjustment co-efficient $\left(\beta_{2}\right)$ appears to be greater in spot than the futures market, indicating that when the co-integrated series is in disequilibrium in the short-run, it is the spot price (cash market) that makes greater adjustment than the futures price (futures market) in order to restore the equilibrium. In other words, futures 
price leads the spot price in price discovery process. From investment strategy perspective, the significantly negative EC term for spot series implies that spot prices are over-valued in all sample markets. In contrast, significantly positive is reported only for NYMEX futures implying that the futures prices in these markets are relatively undervalued. The information provides market traders an incentive to sell/short-sell oil in spot and buys oil futures and exercise lending options to make arbitrage profits. Such an arbitrage process is probably ensuring a long-run equilibrium relationship between spot and futures prices in these markets as confirmed by cointegration results. The causality test reconfirms our findings that there is an observable bilateral causality between all sample futures and spot prices which is stronger from former to latter. In sum, oil futures prices help in discovery of oil spot prices.

Table 3. Johansen cointegration results

\begin{tabular}{|c|c|c|c|c|c|c|c|}
\hline \multicolumn{4}{|c|}{ Trace test } & \multicolumn{4}{|c|}{ Maximum Eigen value test } \\
\hline Null & Alternative & Statistics & $95 \%$ critical value & Null & Alternative & Statistics & $95 \%$ critical value \\
\hline \multicolumn{8}{|c|}{ Cointegration between ICE and SPOT } \\
\hline $\mathrm{r}=0$ & $\mathrm{r}>=1$ & $317.806^{* *}$ & 25.872 & $\mathrm{r}=0$ & $\mathrm{r}=1$ & $313.19 * *$ & 19.387 \\
\hline $\mathrm{r}<=1$ & $\mathrm{r}>=2$ & 4.614 & 12.518 & $\mathrm{r}<=1$ & $\mathrm{r}=2$ & 4.614 & 12.518 \\
\hline $\mathrm{r}<=2$ & $\mathrm{r}>=3$ & & & $\mathrm{r}<=2$ & $\mathrm{r}=3$ & & \\
\hline \multicolumn{8}{|c|}{ Cointegration between $M C X$ and $M C X S P O T$} \\
\hline $\mathrm{r}=0$ & $\mathrm{r}>=1$ & $258.953 * *$ & 25.872 & $\mathrm{r}=0$ & $\mathrm{r}=1$ & $254.78^{* *}$ & 19.387 \\
\hline $\mathrm{r}<=1$ & $\mathrm{r}>=2$ & 4.167 & 12.518 & $\mathrm{r}<=1$ & $\mathrm{r}=2$ & 4.167 & 12.518 \\
\hline $\mathrm{r}<=2$ & $\mathrm{r}>=3$ & & & $\mathrm{r}<=2$ & $\mathrm{r}=3$ & & \\
\hline \multicolumn{8}{|c|}{ Cointegration between NYMEX and SPOT } \\
\hline $\mathrm{r}=0$ & $\mathrm{r}>=1$ & $278.88^{* *}$ & 25.872 & $\mathrm{r}=0$ & $\mathrm{r}=1$ & $274.09^{* *}$ & 19.387 \\
\hline $\mathrm{r}<=1$ & $\mathrm{r}>=2$ & 4.782 & 12.517 & $\mathrm{r}<=1$ & $\mathrm{r}=2$ & 4.782 & 12.517 \\
\hline $\mathrm{r}<=2$ & $\mathrm{r}>=3$ & & & $\mathrm{r}<=2$ & $\mathrm{r}=3$ & & \\
\hline \multicolumn{8}{|c|}{ Cointegration between ICE and NYMEX } \\
\hline $\mathrm{r}=0$ & $\mathrm{r}>=1$ & $252.167 * *$ & 15.494 & $\mathrm{r}=0$ & $\mathrm{r}=1$ & $248.64 * *$ & 14.264 \\
\hline $\mathrm{r}<=1$ & $\mathrm{r}>=2$ & 3.517 & 3.841 & $\mathrm{r}<=1$ & $\mathrm{r}=2$ & 3.517 & 3.841 \\
\hline $\mathrm{r}<=2$ & $\mathrm{r}>=3$ & & & $\mathrm{r}<=2$ & $\mathrm{r}=3$ & & \\
\hline \multicolumn{8}{|c|}{ Cointegration between ICE and MCX } \\
\hline $\mathrm{r}=0$ & $\mathrm{r}>=1$ & $150.53^{* *}$ & 25.872 & $\mathrm{r}=0$ & $\mathrm{r}=1$ & $146.94 * *$ & 19.387 \\
\hline $\mathrm{r}<=1$ & $\mathrm{r}>=2$ & 3.596 & 12.517 & $\mathrm{r}<=1$ & $\mathrm{r}=2$ & 3.596 & 12.517 \\
\hline $\mathrm{r}<=2$ & $\mathrm{r}>=3$ & & & $\mathrm{r}<=2$ & $\mathrm{r}=3$ & & \\
\hline \multicolumn{8}{|c|}{ Cointegration between NYMEX and MCX } \\
\hline $\mathrm{r}=0$ & $\mathrm{r}>=1$ & $167.92 * *$ & 25.872 & $\mathrm{r}=0$ & $\mathrm{r}=1$ & $164.36^{* *}$ & 19.387 \\
\hline $\mathrm{r}<=1$ & $\mathrm{r}>=2$ & 3.558 & 12.517 & $\mathrm{r}<=1$ & $\mathrm{r}=2$ & 3.558 & 12.517 \\
\hline $\mathrm{r}<=2$ & $\mathrm{r}>=3$ & & & $\mathrm{r}<=2$ & $\mathrm{r}=3$ & & \\
\hline
\end{tabular}

Notes: a) * indicates level of significance at $1 \%$, based of which order of integration is decided. b). The lag structure is decided based on the minimum values of the Akaike information Criterion.

Table 4. Estimated co-efficient of VEC model

\begin{tabular}{|c|c|c|c|}
\hline Commodity & Co-efficient & Commodity & Co-efficient \\
\hline \multirow[t]{2}{*}{$\beta_{1 \text { (ice/spot) }}$} & -0.048 & $\beta_{2 \text { (spot/ice) }}$ & -0.35 \\
\hline & {$[-0.893]$} & & {$[-6.367]^{* *}$} \\
\hline \multirow{2}{*}{$\beta_{1(\mathrm{mcx} / \mathrm{mcxspot})}$} & -0.102 & $\beta_{2(\mathrm{mcxspot} / \mathrm{mcx})}$ & -0.499 \\
\hline & {$[-1.869]$} & & {$[-11.242]^{* *}$} \\
\hline \multirow[t]{2}{*}{$\beta_{1 \text { (nymex/spot) }}$} & 0.285 & $\beta_{2 \text { (spot/nymex) }}$ & -0.767 \\
\hline & {$[2.918]^{* *}$} & & {$[-7.959]^{* *}$} \\
\hline \multirow[t]{2}{*}{$\beta_{1 \text { (ice/nymex) }}$} & -0.133 & $\beta_{2 \text { (nymex/ice) }}$ & -0.834 \\
\hline & {$[-1.091]$} & & {$[-6.959]^{* *}$} \\
\hline \multirow[t]{2}{*}{$\beta_{1 \text { (ice/mcx) }}$} & -0.146 & $\beta_{2(\mathrm{mcx} / \mathrm{ice})}$ & -0.333 \\
\hline & {$[-2.068]^{* *}$} & & {$[-5.436]^{* *}$} \\
\hline \multirow[t]{2}{*}{$\beta_{1 \text { (nymex/mcx) }}$} & -0.257 & $\beta_{2 \text { (mcx/nymex) }}$ & -0.244 \\
\hline & {$[-4.072]^{* *}$} & & {$[-4.472]^{* *}$} \\
\hline
\end{tabular}

Notes: values in parentheses [ ] show t-values. ${ }^{* *}$ denotes the level of significance at $1 \%$ and better. 
In cross market analysis, a long-run equilibrium relationship is again confirmed between futures prices of all sample markets, there are significant EC terms for all futures series with the exception of ICE/NYMEX, thereby implying that any departures from equilibrium are significant. Based on the magnitude of EC co-efficient and its statistical significance, it can be inferred that among all three futures markets, it is the ICE which leads NYMEX and MCX futures markets in price discovery process. In other words, ICE futures prices assimilate new information quicker than NYMEX and MCX. Strikingly, in case of NYMEX and MCX futures prices, speed of adjustment is by and large same, indicating that MCX is fastly getting integrated with global trading platforms in case of oil. From global investor's perspective, the ICE futures seem to be relatively over-valued owing to as depicted by significantly negative coefficient. The arbitrage process may involve selling ICE futures and buying NYMEX futures to reap short-term profits. The causality tests provide a reconfirmation that ICE seems to be the dominant platform in the crude oil price discovery process followed by NYMEX and then MCX. However, the price discovery results of VECM are further substantiated by the Granger causality results (see Table 5). The results indicate bidirectional causal relationship between spot and futures prices of sample oil markets with stronger causality moving from futures to spot. Indicating that futures price leads the spot price in price discovery process. However, among three oil trading platforms prices analysed pairwise, it appears that ICE strongly Granger causes NYMEX and MCX as the magnitude of F-statistics of ICE is found to be higher than MCX and NYMEX. In case of between NYMEX and MCX, NYMEX stronger Granger causes MCX, implying that in international oil market, ICE futures prices assimilate new market information quicker than NYMEX and MCX for price discovery.

Table 5. Granger causality results

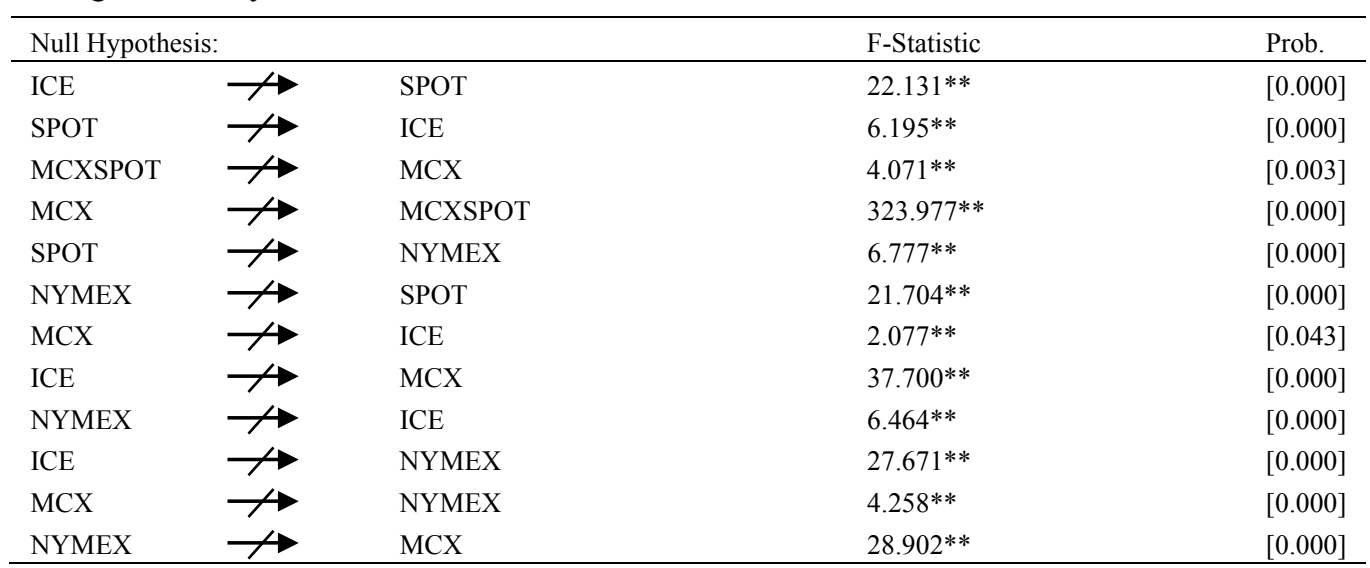

Notes: shows null hypothesis does not Granger Cause. Values in parentheses are p-values. ${ }^{* *}$ denotes the level of significance at $5 \%$ and better.

\subsection{Volatility Spillovers Process}

The estimated results of GARCH-BEKK model to examine the volatility spillovers among sample countries are shown in Table 6 (Panel A to F). The volatility spillover results between ICE futures and its SPOT shown in Panel (A) confirm that there is ARCH effect only in case of SPOT. This implies that past innovations of SPOT prices have significant and positive impact on the current SPOT volatility. Turning to cross volatility spillover effects in the short-run, the results indicate that there are bilateral volatility spillovers between ICE and SPOT prices with stronger volatility spillover moving from ICE futures to SPOT. It may be noted that in case of ICE, the past innovations in spot prices impact the current futures price volatility positively while exactly opposite is the case from futures to spot. With respect to long-term effects of ICE futures and spot, the results indicate that there is strong evidence of volatility persistence, implying that there is strong GARCH effect in case of futures and spot. This further means that the past volatility of current futures/spot prices impacts the current volatility futures/spot significantly. Surprisingly, the volatility persistence appears to be stronger in futures compared to spot. Turning to cross market long-term volatility spillovers, the results indicate that there are bilateral volatility spillovers between spot and futures with stronger volatility spillover moving from futures to spot. It may here be noted that unlike short-term, the past volatility of SPOT impacts the current volatility of futures (ICE) negatively while futures price volatility spot price volatility positively.

Similarly, in case of MCX in the short-run, the spillover results indicate that there is no ARCH effect in futures and spot prices. While, there is unilateral volatility spillover moving from futures to spot. The spillover appears 
to be negative implying that the past innovations in futures market impact the current spot market inversely in the short-term. With respect to long-term spillovers, the results indicate strong evidence of volatility persistence in case of futures and spot prices. The results imply that the past volatility of futures and spot impact their current futures and spot considerably. Strikingly, there appears to be no long-term cross-market volatility spillovers between spot and futures prices in case of MCX. With respect to NYMEX (see Panel C), the results indicate that there is a positive short-term clustering in case of SPOT prices. Surprisingly, there is no cross-market spillover implying that in the short-term, it is only the SPOT market which bears the impact of past innovations in the market. Turning to long-term volatility spillovers, the results indicate no evidence of volatility persistence. However, there is a negative volatility spillover moving from futures to spot, while, inverse is not found.

Table 6. MGARCH results

Panel A. ICE-SPOT

\begin{tabular}{|c|c|c|c|c|c|c|}
\hline \multirow{2}{*}{ Variables } & \multicolumn{2}{|l|}{ BEKK } & \multicolumn{2}{|l|}{$\mathrm{CCC}$} & \multicolumn{2}{|l|}{ DCC } \\
\hline & Coeff. & t-stat & Coeff. & t-stat & Coeff. & t-stat \\
\hline$\mu_{1}$ & 0.032 & {$[0.951]$} & 0.062 & {$[2.248] *$} & 0.053 & {$[2.097] *$} \\
\hline$\mu_{2}$ & 0.032 & [1.093] & 0.061 & {$[2.409] *$} & 0.051 & {$[2.218] *$} \\
\hline $\mathrm{c}_{(1,1)}$ & 0.037 & [1.259] & 0.039 & {$[2.505] *$} & 0.037 & {$[2.175] *$} \\
\hline $\mathbf{c}_{(2,1)}$ & -0.133 & {$[-1.884]$} & & & & \\
\hline $\mathbf{c}_{(2,2)}$ & 0.001 & {$[0.002]$} & 0.047 & {$[2.285] *$} & 0.042 & {$[2.021] *$} \\
\hline$\alpha_{(1,1)}$ & -0.105 & {$[-1.339]$} & 0.079 & {$[3.248] *$} & 0.086 & {$[2.013] *$} \\
\hline$\alpha_{(1,2)}$ & -0.656 & {$[-6.492]^{*}$} & & & & \\
\hline$\alpha_{(2,1)}$ & 0.215 & {$[2.705] *$} & & & & \\
\hline$\alpha_{(2,2)}$ & 0.584 & {$[5.191]$ * } & 0.107 & {$[2.682] *$} & 0.108 & {$[2.213] *$} \\
\hline$\beta_{(1,1)}$ & 1.186 & {$[53.072] *$} & 0.869 & {$[22.399] *$} & 0.855 & {$[13.571]^{*}$} \\
\hline$\beta_{(1,2)}$ & 0.647 & {$[5.021]^{*}$} & & & & \\
\hline$\beta_{(2,1)}$ & -0.212 & {$[-9.201] *$} & & & & \\
\hline$\beta_{(2,2)}$ & 0.325 & {$[2.394] *$} & 0.832 & {$[14.318] *$} & 0.822 & {$[11.065]$ * } \\
\hline$\rho_{(2,1)}$ & & & 0.934 & {$[78.323] *$} & & \\
\hline$\theta_{(1)}$ & & & & & 0.019 & {$[0.884]$} \\
\hline$\theta_{(2)}$ & & & & & 0.565 & {$[8.372] *$} \\
\hline Log likelihood & -2459.49 & & -2618.61 & & -2596.76 & \\
\hline
\end{tabular}

Panel B. MCX-SPOT

\begin{tabular}{|c|c|c|c|c|c|c|}
\hline \multirow{2}{*}{ Variables } & \multicolumn{2}{|l|}{ BEKK } & \multicolumn{2}{|l|}{$\mathrm{CCC}$} & \multicolumn{2}{|l|}{ DCC } \\
\hline & Coeff & t-Stat & Coeff & t-Stat & Coeff & t-Stat \\
\hline$\mu_{1}$ & 0.030 & [1.379] & 0.039 & [1.693] & 0.037 & [1.521] \\
\hline$\mu_{2}$ & 0.027 & {$[1.283]$} & 0.036 & [1.651] & 0.041 & [1.777] \\
\hline $\mathrm{c}_{(1,1)}$ & 0.123 & [1.827] & 0.021 & {$[3.32] *$} & 0.021 & {$[3.523] *$} \\
\hline $\mathrm{c}_{(2,1)}$ & -0.135 & {$[-1.613]$} & & & & \\
\hline $\mathrm{c}_{(2,2)}$ & 0.013 & {$[0.143]$} & 0.034 & [1.759] & 0.033 & {$[2.265] *$} \\
\hline$\alpha_{(1,1)}$ & 0.185 & [1.510] & 0.056 & {$[4.22] *$} & 0.059 & {$[4.587] *$} \\
\hline$\alpha_{(1,2)}$ & -0.219 & {$[-2.034]^{*}$} & & & & \\
\hline$\alpha_{(2,1)}$ & 0.031 & {$[0.353]$} & & & & \\
\hline$\alpha_{(2,2)}$ & 0.224 & [1.885] & 0.102 & {$[2.44] *$} & 0.108 & {$[3.443] *$} \\
\hline$\beta_{(1,1)}$ & 0.971 & {$[23.27] *$} & 0.919 & {$[59.14] *$} & 0.918 & {$[56.56] *$} \\
\hline$\beta_{(1,2)}$ & 0.104 & [1.679] & & & & \\
\hline$\beta_{(2,1)}$ & -0.002 & {$[-0.064]$} & & & & \\
\hline$\beta_{(2,2)}$ & 0.909 & {$[14.27] *$} & 0.862 & {$[15.48]^{*}$} & 0.861 & {$[21.31] *$} \\
\hline$\rho_{(2,1)}$ & & & 0.544 & {$[27.56] *$} & & \\
\hline$\theta_{(1)}$ & & & & & 0.056 & {$[4.10] *$} \\
\hline$\theta_{(2)}$ & & & & & 0.399 & [1.877] \\
\hline Log likelihood & -4198.67 & & -4200.06 & & -4192.02 & \\
\hline
\end{tabular}


Panel C. NYMEX-SPOT

\begin{tabular}{|c|c|c|c|c|c|c|}
\hline \multirow{2}{*}{ Variables } & \multicolumn{2}{|l|}{ BEKK } & \multicolumn{2}{|l|}{$\mathrm{CCC}$} & \multicolumn{2}{|l|}{ DCC } \\
\hline & Coeff. & t-stat & Coeff. & t-stat & Coeff. & t-stat \\
\hline$\mu_{1}$ & 0.021 & [0.539] & 0.021 & {$[0.529]$} & 0.026 & {$[0.977]$} \\
\hline$\mu_{2}$ & 0.025 & {$[0.724]$} & 0.023 & {$[0.537]$} & 0.029 & {$[1.024]$} \\
\hline $\mathrm{c}_{(1,1)}$ & 0.932 & {$[20.510]^{*}$} & 0.074 & {$[2.638]^{*}$} & 0.040 & {$[3.047]^{*}$} \\
\hline $\mathbf{c}_{(2,1)}$ & 0.927 & {$[23.319]^{*}$} & & & & \\
\hline $\mathbf{c}_{(2,2)}$ & 0.000 & {$[-0.006]$} & 0.077 & {$[2.511]^{*}$} & 0.042 & {$[2.858]^{*}$} \\
\hline$\alpha_{(1,1)}$ & 0.318 & {$[1.281]$} & 0.285 & {$[3.372]^{*}$} & 0.189 & {$[6.397]^{*}$} \\
\hline$\alpha_{(1,2)}$ & -0.408 & {$[-1.291]$} & & & & \\
\hline$\alpha_{(2,1)}$ & 0.029 & {$[0.132]$} & & & & \\
\hline$\alpha_{(2,2)}$ & 0.641 & {$[2.389]^{*}$} & 0.301 & {$[3.633]^{*}$} & 0.190 & {$[5.036]^{*}$} \\
\hline$\beta_{(1,1)}$ & -0.493 & {$[-1.541]$} & 0.666 & {$[11.52]^{*}$} & 0.728 & {$[35.35]^{*}$} \\
\hline$\beta_{(1,2)}$ & -1.139 & {$[-3.069]^{*}$} & & & & \\
\hline$\beta_{(2,1)}$ & 0.489 & {$[0.912]$} & & & & \\
\hline$\beta_{(2,2)}$ & 1.087 & {$[1.783]$} & 0.651 & {$[10.315]^{*}$} & 0.721 & {$[23.17]^{*}$} \\
\hline$\rho_{(2,1)}$ & & & 0.974 & {$[252.50]^{*}$} & & \\
\hline$\theta_{(1)}$ & & & & & 0.083 & {$[1.250]$} \\
\hline$\theta_{(2)}$ & & & & & 0.640 & {$[0.000]$} \\
\hline Log likelihood & -1527.9 & & -1896.8 & & -1929.4 & \\
\hline \multicolumn{7}{|c|}{ Panel D. ICE-NYMEX } \\
\hline \multirow{2}{*}{ Variables } & \multicolumn{2}{|l|}{ BEKK } & \multicolumn{2}{|l|}{$\mathrm{CCC}$} & \multicolumn{2}{|l|}{ DCC } \\
\hline & Coeff & t-stats & Coeff & $\mathrm{t}$-stats & Coeff & $\mathrm{t}$-stats \\
\hline$\mu_{1}$ & 0.000 & {$[0.010]$} & 0.086 & {$[2.671] *$} & 0.004 & {$[2.525] *$} \\
\hline$\mu_{2}$ & 0.003 & {$[0.092]$} & 0.084 & {$[2.595] *$} & 0.006 & [1.995]* \\
\hline $\mathrm{c}_{(1,1)}$ & 0.119 & {$[1.006]$} & 0.028 & {$[1.749]$} & 0.026 & {$[92.4] *$} \\
\hline $\mathrm{c}_{(2,1)}$ & -0.069 & {$[-0.919]$} & & & & \\
\hline $\mathbf{c}_{(2,2)}$ & 0.000 & {$[0.000]$} & 0.029 & {$[1.631]$} & 0.027 & {$[207.8]^{*}$} \\
\hline$\alpha_{(1,1)}$ & 0.061 & {$[0.537]$} & 0.072 & {$[1.646]$} & 0.063 & {$[215.2] *$} \\
\hline$\alpha_{(1,2)}$ & -0.072 & {$[-0.652]$} & & & & \\
\hline$\alpha_{(2,1)}$ & -0.046 & {$[-0.448]$} & & & & \\
\hline$\alpha_{(2,2)}$ & -0.111 & {$[-0.970]$} & 0.084 & {$[1.616]$} & 0.076 & {$[985.2] *$} \\
\hline$\beta_{(1,1)}$ & -0.650 & {$[-2.662]^{*}$} & 0.891 & {$[19.15] *$} & 0.891 & {$[816.8] *$} \\
\hline$\beta_{(1,2)}$ & -0.367 & {$[-0.829]$} & & & & \\
\hline$\beta_{(2,1)}$ & 1.586 & {$[7.305] *$} & & & & \\
\hline$\beta_{(2,2)}$ & 1.324 & {$[3.144] *$} & 0.878 & {$[15.50]^{*}$} & 0.875 & {$[142.1]^{*}$} \\
\hline$\rho_{(2,1)}$ & & & 0.954 & {$[77.86]^{*}$} & & \\
\hline$\theta_{(1)}$ & & & & & 0.041 & {$[-0.048]$} \\
\hline$\theta_{(2)}$ & & & & & 0.959 & {$[2.210] *$} \\
\hline Log likelihood & -2270.08 & & -2341.50 & & -2234.50 & \\
\hline
\end{tabular}


Panel E. ICE-MCX

\begin{tabular}{|c|c|c|c|c|c|c|}
\hline \multirow{2}{*}{ Variables } & \multicolumn{2}{|l|}{ BEKK } & \multicolumn{2}{|l|}{$\mathrm{CCC}$} & \multicolumn{2}{|l|}{$\mathrm{DCC}$} \\
\hline & Coeff & t-stat & Coeff & t-stat & Coeff & t-stat \\
\hline$\mu_{1}$ & 0.038 & {$[2.032]^{*}$} & 0.045 & {$[1.970]$} & 0.046 & [1.896] \\
\hline$\mu_{2}$ & 0.023 & [1.234] & 0.045 & [1.799] & 0.037 & [1.424] \\
\hline $\mathrm{c}_{(1,1)}$ & 0.198 & {$[5.142]^{*}$} & 0.012 & [1.807] & 0.019 & {$[2.46] *$} \\
\hline $\mathrm{c}_{(2,1)}$ & 0.062 & {$[1.287]$} & & & & \\
\hline $\mathrm{c}_{(2,2)}$ & 0.000 & {$[0.000]$} & 0.014 & {$[2.593] *$} & 0.016 & {$[2.788] *$} \\
\hline$\alpha_{(1,1)}$ & 0.470 & {$[5.091] *$} & 0.058 & {$[2.839] *$} & 0.087 & {$[4.401] *$} \\
\hline$\alpha_{(1,2)}$ & 0.051 & {$[0.476]$} & & & & \\
\hline$\alpha_{(2,1)}$ & 0.215 & {$[2.896] *$} & & & & \\
\hline$\alpha_{(2,2)}$ & 0.190 & {$[2.355] *$} & 0.058 & {$[2.890] *$} & 0.079 & {$[4.77] *$} \\
\hline$\beta_{(1,1)}$ & 0.901 & {$[19.20] *$} & 0.926 & {$[32.76] *$} & 0.890 & {$[35.9] *$} \\
\hline$\beta_{(1,2)}$ & 0.104 & {$[2.152] *$} & & & & \\
\hline$\beta_{(2,1)}$ & 0.032 & {$[0.535]$} & & & & \\
\hline$\beta_{(2,2)}$ & 0.897 & {$[21.40] *$} & 0.925 & {$[41.37] *$} & 0.903 & {$[52.51] *$} \\
\hline$\rho_{(2,1)}$ & & & 0.839 & {$[66.80] *$} & & \\
\hline$\theta_{(1)}$ & & & & & 0.058 & {$[3.23] *$} \\
\hline$\theta_{(2)}$ & & & & & 0.927 & {$[40.12] *$} \\
\hline Log likelihood & -3285.44 & & -3359.80 & & -3307.27 & \\
\hline
\end{tabular}

\section{Panel F. NYMEX-MCX}

\begin{tabular}{|c|c|c|c|c|c|c|}
\hline \multirow{2}{*}{ Variables } & \multicolumn{2}{|l|}{ BEKK } & \multicolumn{2}{|l|}{$\mathrm{CCC}$} & \multicolumn{2}{|l|}{ DCC } \\
\hline & Coeff. & t-stat & Coeff. & t-stat & Coeff. & t-stat \\
\hline$\mu_{1}$ & 0.027 & [1.429] & 0.058 & {$[2.104] *$} & 0.034 & [1.388] \\
\hline$\mu_{2}$ & 0.035 & {$[2.051]^{*}$} & 0.055 & {$[2.548] *$} & 0.032 & [1.380] \\
\hline $\mathrm{c}_{(1,1)}$ & 0.084 & {$[2.106] *$} & 0.016 & {$[2.129] *$} & 0.017 & {$[2.208] *$} \\
\hline $\mathrm{c}_{(2,1)}$ & 0.231 & {$[8.418] *$} & & & & \\
\hline $\mathrm{c}_{(2,2)}$ & 0.000 & {$[-0.001]$} & 0.015 & {$[2.058] *$} & 0.022 & {$[2.076] *$} \\
\hline$\alpha_{(1,1)}$ & 0.155 & [1.655] & 0.050 & {$[3.158] *$} & 0.079 & {$[3.881] *$} \\
\hline$\alpha_{(1,2)}$ & -0.272 & {$[-4.25] *$} & & & & \\
\hline$\alpha_{(2,1)}$ & -0.002 & {$[-0.013]$} & & & & \\
\hline$\alpha_{(2,2)}$ & 0.589 & {$[7.342] *$} & 0.060 & {$[2.787] *$} & 0.099 & {$[3.262] *$} \\
\hline$\beta_{(1,1)}$ & 0.909 & {$[26.29] *$} & 0.929 & {$[50.24] *$} & 0.905 & {$[46.91] *$} \\
\hline$\beta_{(1,2)}$ & 0.062 & [1.097] & & & & \\
\hline$\beta_{(2,1)}$ & 0.089 & {$[2.034] *$} & & & & \\
\hline$\beta_{(2,2)}$ & 0.839 & {$[16.58] *$} & 0.919 & {$[34.21] *$} & 0.878 & {$[26.47] *$} \\
\hline$\rho_{(2,1)}$ & & & 0.807 & {$[55.29] *$} & & \\
\hline$\theta_{(1)}$ & & & & & 0.097 & {$[2.481] *$} \\
\hline$\theta_{(2)}$ & & & & & 0.877 & {$[18.45] *$} \\
\hline Log likelihood & -3392.56 & & -3496.68 & & -3433.39 & \\
\hline
\end{tabular}

Notes: Models estimated using QMLE with robust (heteroskedasticity/misspecification) standard errors. $\mu_{\mathrm{i}}$ denotes the mean equation coefficients. In the variance equations, c denotes the constant terms, $\alpha$ denotes the ARCH terms and $\beta$ denotes the GARCH terms. The coefficient $\alpha_{12}$ for example can be interpreted as the short-term volatility spillover moving from ICE futures to its SPOT in Panel, rest of the panels are also interpreted in the same manner, respectively. While, $\beta_{12}$ represents the long-term volatility spillover from ICE to SPOT for is interpreted in the same manner as above. * denotes the level of significance at $5 \%$ and better for panels A toF, respectively.

In sum, we confirm bilateral volatility spillover between ICE futures and spot in both futures as well as spot in the long-run which is stronger from former to latter. Further, a unilateral volatility spillover from futures to spot is confirmed for MCX in the short-term and for NYMEX only in the long-term. Thus, the oil futures seem to have a destabilizing effect on spot prices which should be of concern to policy makers and regulators. With respect to futures markets volatility spillovers involving futures prices, we start with ICE and NYMEX results which indicate that there are no significant own as well as cross-market spillovers in the short-term (see Panel D). The long-term volatility spillover results exhibit high volatility persistence in case of both ICE as well as NYMEX. This implies that the past volatility of ICE and NYMEX impact their current volatility considerably. With respect to cross-market spillover, the results indicate only one way volatility spillover moving from 
NYMEX to ICE. This is in contrast with price discovery results especially the Granger causality which indicates ICE as the lead market. The results of volatility spillover have strong implications as it indicates that the past volatility of NYMEX impacts current volatility of ICE futures prices. However, the results of ICE and MCX (see Panel E) indicate that in the short-term, there is strong evidence of volatility clustering in both ICE and MCX futures prices. The results of short-term cross-market volatility spillovers indicate that there is one-way spillover moving from MCX to ICE. In the long-term, the results indicate that there is strong evidence of high volatility persistence in case of ICE and MCX, implying that there are significant impacts of past volatility on current volatility of ICE and MCX futures prices. Turning to cross-market volatility spillover, the results indicate that there is unilateral volatility spillover moving from ICE to MCX. The long-term results are in line with price discovery results indicating the dominance of ICE over MCX. Lastly, we analyse the spillover results of MCX and NYMEX. The results further indicate that in the short-run, own volatility spillovers are high for MCX while in case of NYMEX this is not the case. With respect to short-term cross market volatility spillover, the results indicate that negative and unilateral volatility spillovers moving from NYMEX to MCX. The negative volatility spillover co-efficient indicate that the past innovations of NYMEX indicate the current volatility of MCX significantly. Turning to long-term results, it appears that there is strong evidence of volatility persistence in both markets, implying that there is impact of past volatility of futures prices on current volatility of futures prices. With respect to cross-market volatility, the results indicate that there is unilateral volatility spillover moving from MCX to NYMEX. The results imply that in contrast to the short-term, in the long-term, past volatility of MCX appears to have stronger impact on current volatility of NYMEX.

To summarize, we can say that the volatility spillover results are more or less in line with price discovery results. Turning to cross-market volatility spillover, there is a case of unilateral volatility spillover in each market, implying that the information flow across markets is not symmetric. However, there is also strong finding that comes out from this study is the evidence of strong volatility persistence in most of the sample markets. This implies that own volatility spillover is stronger than the cross-market spillovers. The possible explanation could be due to the domestic reasons such as longer trading hours, presence of more noise trader than value traders and regulatory regime which could have strong bearing on the market. However, the spot and futures market results indicate that it is the futures price which assimilates new information quicker than spot in each sample market with the exception of MCX. Turning to cross-market volatility spillovers, the results indicate that between ICE and NYMEX, the volatility spillover of NYMEX appears to have stronger effect on ICE. Similarly in case of ICE and MCX, the spillover impact of MCX is stronger in the short-term while in the long-term ICE dominates over MCX. While, MCX futures price volatility impacts NYMEX futures price volatility. NYMEX seems to be the dominant market vis-a-vis ICE while the later more dominant platform in price discovery process.

Turning to constant and time-varying dynamic conditional correlations, the results of CCC model suggest that there is strong correlation between each pair of market. But based on the magnitude of correlations, it appears that the correlation is high between NYMEX and its SPOT (0.97) and is significant followed by ICE and its SPOT (0.93) and MCX and its MCXSPOT (0.54). With respect to cross market correlations, the results indicate the high correlation between ICE and NYMEX (0.95) followed by ICE and MCX (0.83) and MCX and NYMEX $(0.80)$. The CCC model provides interesting results. MCX futures exhibit greater association with international counterpart exchanges then its local spot market. This implies that emerging market platforms like MCX exhibit greater integration with international markets than at domestic level. This may be due to nature of oil as an international commodity and the possible market microstructure differences between futures and spot markets, making the former more informationally linked to each other than to their cash counterpart. Turning to DCC results, the estimated coefficients of $\theta_{(1)}$ and $\theta_{(2)}$ are high in each case except ICE with its SPOT and MCX with its MCXSPOT. 

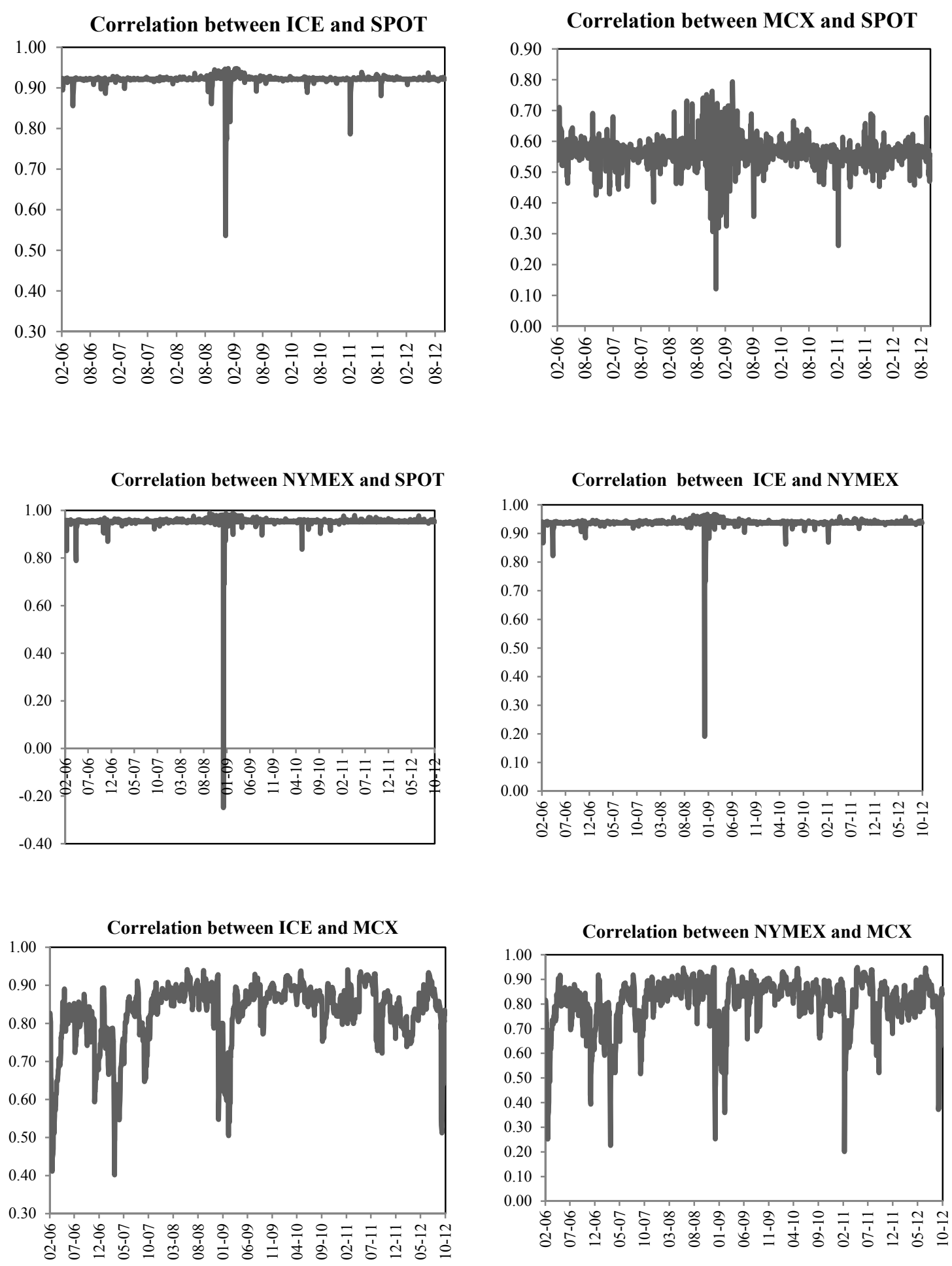

Figure 3. Time -varying conditional correlations from the DCC model

\subsection{Dynamic Conditional Correlations}

Figure 3 shows the time-varying DCC correlations. The results between futures and spot prices of sample markets indicate the evidence of volatility clustering in each case. But there appears to be stronger volatility clustering in case of MCX. The DCC patterns in case of ICE and SPOT, the magnitude of correlation coefficients are high (0.90) indicating the strong evidence of co-movement. The similar DCC patterns are also seen in case of NYMEX and SPOT. In case of MCX, the dynamic conditional correlations are high and ranges from 0.10 to 
0.80. The dynamic conditional correlation of within markets indicates the up until 2008 there is not much variation in correlations. There appears to be strong variation in correlations around October, 2008 then shoot up around June, 2009. Seemingly, there is again fall in correlation around October, 2010 then again went up afterwards, indicating the strong impact of global financial crisis and Eurozone turmoil. Turning to cross market volatility spillovers, there is not much variation in DCC in case of ICE and NYMEX but there are apparent ups and downs in dynamic conditional correlations of ICE and MCX and NYMEX and MCX. The magnitudes of dynamic conditional correlations among the three pairs are ranging from 0.20 to 0.90 . The correlation patterns of ICE and NYMEX are in tandem with within market correlations. The correlation patterns of ICE and MCX and MCX and NYMEX reached low values around March, 2007, October, 2008 and October, 2010. After that there is sudden jump in the magnitude of correlations co-efficient and reaches up to 0.90 . This implies that during crisis period, the dynamic conditional correlations are generally lower and increases significantly afterwards. The possible reasons could be because of the sudden fall in demand during crisis period and once economies are bottomed out and demand resurges, closer comovement is observed between the alternative oil markets (see Sadorsky, 2012). However, it appears that there is again fall in dynamic conditional correlations during June, 2012 to October, 2012, as can be observed from the graph. To conclude, we can say that there is a clear trend in the dynamic conditional correlations patterns of examined markets during crisis event and normally the correlations appear to be higher afterwards. Finally, we go for diagnostic checking of the model, the diagnostic tests for the standardized residuals and its squared values exhibit no evidence of serial correlation at the $1 \%$ level across all the models applied (see Table 7).

Table 7. Diagnostic tests for standardized residuals

\begin{tabular}{lllllll}
\hline & \multicolumn{3}{l}{$\mathrm{BEKK}$} & \multicolumn{3}{c}{$\mathrm{DCC}$} \\
\cline { 2 - 7 } & $\mathrm{Q}_{(20)}$ & $\mathrm{Q}_{\text {sqr }(20)}$ & $\mathrm{Q}_{(20)}$ & $\mathrm{Q}_{\text {sqr }(20)}$ & $\mathrm{Q}_{(20)}$ & $\mathrm{Q}_{\text {sqr }(20)}$ \\
\hline ICE/SPOT & 24.818 & 24.365 & 27.179 & 24.995 & 27.449 & 25.141 \\
& {$[0.209]$} & {$[0.227]$} & {$[0.130]$} & {$[0.202]$} & {$[0.123]$} & {$[0.196]$} \\
ICE/NYMEX & 23.836 & 28.986 & 25.222 & 28.706 & 25.502 & 28.781 \\
& {$[0.250]$} & {$[0.088]$} & {$[0.193]$} & {$[0.094]$} & {$[0.183]$} & {$[0.092]$} \\
ICE/MCX & 31.081 & 23.874 & 28.183 & 21.664 & 28.347 & 21.365 \\
& {$[0.054]$} & {$[0.248]$} & {$[0.105]$} & {$[0.359]$} & {$[0.101]$} & {$[0.376]$} \\
MCX/SPOT & 18.018 & 21.008 & 17.685 & 19.667 & 17.651 & 19.569 \\
& {$[0.586]$} & {$[0.480]$} & {$[0.608]$} & {$[0.620]$} & {$[0.610]$} & {$[0.620]$} \\
NYMEX/MCX & 23.470 & 26.219 & 19.869 & 32.436 & 19.446 & 32.973 \\
& {$[0.266]$} & {$[0.131]$} & {$[0.466]$} & {$[0.039]$} & {$[0.493]$} & {$[0.034]$} \\
NYMEX/SPOT & 26.614 & 30.618 & 19.431 & 15.623 & 19.313 & 15.413 \\
& {$[0.113]$} & {$[0.080]$} & {$[0.494]$} & {$[0.740]$} & {$[0.502]$} & {$[0.752]$} \\
\hline
\end{tabular}

Note: values in parentheses are p-values.

\section{Conclusion}

This paper examines the price discovery and volatility spillovers between spot and futures and between futures prices of three markets viz., ICE, MCX and NYMEX. The results confirm the price discovery between spot and futures and among sample futures markets. Between spot and futures, the futures price leads the spot price in price discovery process, implying that futures prices assimilate new market information quicker than spot in all sample markets which is in contrast with Goyal and Tripathi (2012). The results of futures prices of three markets analysed pairwise indicate that ICE is the more dominant market followed by NYMEX and MCX in terms of price discovery. Causality test results further confirm a two way information transmission between spot and futures markets which is stronger from former to the later. Two-ways information linkages between pair of futures markets which are stronger from ICE to NYMEX, ICE to MCX and NYMEX to MCX. The volatility spillover results indicate that it is the futures price which assimilates new information quicker than spot in each sample market with the exception of MCX. Turning to cross-market volatility spillovers, the results show that between ICE and NYMEX, the volatility spillover of NYMEX appears to have stronger effect on ICE. Similarly in case of ICE and NYMEX, the spillover impact of MCX is stronger in the short-term while in the long-term ICE dominates over MCX. Seemingly, between NYMEX and MCX, it is the NYMEX in the short-term which has stronger spillover than MCX. While opposite is the case found in the long-run. Based on the results, we conclude that in terms of volatility spillovers, it is the NYMEX which appears to be dominant market while ICE and MCX appear to be equally competing markets which is in line with Spargoli and Zagaglia (2007). The CCC 
model results show strong co-movement between ICE futures, NYMEX futures and their spot platforms. For MCX, the cross market association (between futures prices) seems to be much stronger than with in market association (between spot and futures), thus implying that emerging market platform for oil is more integrated with its international exchanges than with the domestic spot markets. The DCC results confirm stronger cross market and with in market association confirm weaker during the economic crisis period which seem to become stronger for stable period.

The research has strong implications for policy makers as well as market traders. The mature market trading platforms like ICE and NYMEX seem to be dominant with regard to information dissemination on oil trading vis-à-vis emerging market platforms like MCX which clearly appears to be a satellite market. ICE seems to play leadership role in the international oil price discovery process. Hence, price quote of ICE for WTI crude should be used as a pricing benchmark by world economies including India. Futures markets for oil seem to be more informationally efficient than spot market, as expected. From risk management perspective NYMEX seems to take lead in the information transmission relating to return volatility. International futures prices seem to be more correlated with each other than with the corresponding spot prices, confirming the international nature of oil as a commodity. Finally, oil market integration seems to be stronger during stable phase than during crisis period which may have policy implications for global oil trade.

Further, the futures market volatility does have some destabilizing implications for spot prices, thus indicating that crude prices may be affected by speculative activity besides the demand-supply fundamentals and tax regimes. The market trades may exploit any departures from equilibrium in the short-run by developing appropriate arbitrage strategies. The present study contributes to commodity market literature especially that which deals with information linkages between mature and emerging market platforms and focuses on little explored area of information linkages between mature and emerging market platforms. The study is particularly relevant given the strategic importance of oil in global economy.

\section{Acknowledgements}

The authors are grateful to the editor of this journal and to an anonymous reviewer for valuable comments and suggestions. All errors and omissions are solely ours.

\section{References}

Antoniou, A., \& Foster, A. (1992). The effect of futures trading on spot price volatility: Evidence for Brent Crude oil using GARCH. Journal of Business Finance \& Accounting, 19(4), 473-484. http://dx.doi.org/10.1111/j.1468-5957.1992.tb00639.x

Arouria, H. E., Jouini, J., \& Khuong, N. D. (2012). On the impacts of oil pricefluctuations on European equity markets: Volatility spillover and hedging effectiveness. Energy Economics, 34(2), 611-617. http://dx.doi.org/10.1016/j.eneco.2011.08.009

Baba, Y., Engle, R. F., Kraft, D., \& Kroner, K. (1990). Multivariate simultaneous generalized ARCH. Unpublished Manuscript.

Bekaert, G., \& Harvey, C. R. (1997). Emerging equity market volatility. Journal of Financial Economics, 43(1), 29-77. http://dx.doi.org/10.1016/S0304-405X(96)00889-6

Bekiros, D. S., \& Diks, G. H. (2008). The relationship between crude oil spot and futures prices: Cointegration, linear and nonlinear causality. Energy Economics, 30(5), 2673-2685. http://dx.doi.org/10.1016/j.eneco.2008.03.006

Booth, G. G., Martikainen, T., \& Tse, Y. (1997). Price and volatility spillovers in Scandinavian stock markets. Journal of Banking and Finance, 21(6), 811-823. http://dx.doi.org/10.1016/S0378-4266(97)00006-X

Carter, C. A. (1989). Arbitrage opportunities between thin and liquid futures markets. Journal of Futures Markets, 9(4), 347-353. http://dx.doi.org/10.1002/fut.3990090408

Chakrabarty, R., \& Chakravarty, L. S. (2012). An Econometric Study of Indian Export and Import of Black Gold (oil). Procedia - Social and Behavioral Sciences, 37, 182-196. http://dx.doi.org/10.1016/j.sbspro.2012.03.285

Chan, K., Chan, K. C., \& Karolyi, G. A. (1991). Intraday volatility in the stock index and stock index futures markets. Review of Financial Studies, 4(4), 657-684. http://dx.doi.org/10.1093/rfs/4.4.657

Chiang, T. C., Jeon, B. N., \& Li, H. (2007). Dynamic correlation analysis of financial contagion: Evidence from Asian markets. Journal of International Money and Finance, 26(7), 1206-1228. 
http://dx.doi.org/10.1016/j.jimonfin.2007.06.005

Christofi, A., \& Pericli, A. (1999). Correlation in Price Changes and Volatility of Major Latin American Stock $\begin{array}{lllll}\text { Markets. Journal of Multinational Financial Management, } & 9(1), & \text { 79-93. }\end{array}$ http://dx.doi.org/10.1016/S1042-444X(98)00047-4

Du, X., Yu, L. C., \& Hayes, D. J. (2011). Speculation and volatility spillover in the crude oil and agricultural commodity markets: A Bayesian analysis. Energy Economics, 33(3), 497-503. http://dx.doi.org/10.1016/j.eneco.2010.12.015

Engle, R. F. (2002). Dynamic conditional correlation: A simple class of multivariate generalized autoregressive conditional heteroskedasticity models. Journal of Business \& Economic Statistics, 20(3), 339-350. http://dx.doi.org/10.1198/073500102288618487

Engle, R. F., Ito, T., \& Lin, W. (1990). Meteor showers or heat waves? Heteroscedastic intraday volatility in the foreign exchange market. Econometrica, 58(3), 525-542. http://dx.doi.org/10.2307/2938189

Ewing, B. T., \& Malik, F. (2013). Volatility transmission between gold and oil futures under structural breaks. International Review of Economics and Finance, 25, 113-121. http://dx.doi.org/10.1016/j.iref.2012.06.008

Ewing, T. B., Malik, F., \& Ozfidan, O. (2002). Volatility transmission in the oil and natural gas markets. Energy Economics, 24(6), 525-538. http://dx.doi.org/10.1016/S0140-9883(02)00060-9

Gagnon, 1., \& Karolyi, A. G. (2006). Price and volatility transmisison across borders. Financial Markets, Institutions and Instruments, 17(3), 107-158. http://dx.doi.org/10.1111/j.1468-0416.2006.00115.x

Goyal, A., \& Tripathi, S. (2012). Regulations and price discovery: oil spot and futures markets. Working Paper, Indira Gandhi Institute of Development Research, Mumbai , WP-2012-016, 1-29.

Gregory, A. W., \& Hansen, B. E. (1996). Residual-based tests for cointegration in models with regime shifts. Journal of Econometrics, 70(1), 99-126. http://dx.doi.org/10.1016/0304-4076(69)41685-7

Hamao, Y. R., Masulis, R. W., \& Ng, V. K. (1990). Correlation in price changes and volatility across international stock markets. Review of Financial Studies, 3(2), 281-307. $\mathrm{http}: / / \mathrm{dx}$. doi.org/10.1093/rfs/3.2.281

Hammoudeh, S., \& Yuan, Y. (2008). Metal volatility in presence of oil and interest rate shocks. Energy Economics, 30(2), 606-620. http://dx.doi.org/10.1016/j.eneco.2007.09.004

Hammoudeh, S., Li, H., \& Jeon, B. (2003). Causality and volatility spillovers among petroleum prices of WTI, gasoline and heating oil in different locations. The North American Journal of Economics and Finance, 14(1), 89-114. http://dx.doi.org/10.1016/S1062-9408(02)00112-2

Hong, Y. (2001). A test for volatility spillover with application to exchange rates. Journal of Econometrics, 103(1-2), 183-224. http://dx.doi.org/10.1016/S0304-4076(01)00043-4

Hou, Y., \& Li, S. (2012). Price discovery in Chinese stock index futures market: New evidence based on intraday data. Asia Pacific Financial Markets.

Ji, Q., \& Fan, Y. (2012). How does oil price volatility affect non-energy commodity markets? Applied Energy, 89(1), 273-280. http://dx.doi.org/10.1016/j.apenergy.2011.07.038

Johansen, S., \& Juselius, K. (1992). Testing Structural Hypothesis in a Multivariate Cointegration Analysis of the PPP and UIP for UK. Journal of Econometrics, 53(1-3), 211-244. http://dx.doi.org/10.1016/0304-4076(92)90086-7

Karmakar, M. (2009). Price discoveries and volatility spillovers in S\&P CNX nifty future and its underlying index CNX nifty. Vikalpa, 34(2), 41-56.

Kaufmann, K. R., \& Ullman, B. (2009). Oil prices, speculation, and fundamentals: Interpreting causal relations among spot and futures prices. Energy Economics, 31(4), 550-558. http://dx.doi.org/10.1016/j.eneco.2009.01.013

Koutmos, G., \& Booth, G. G. (1995). Asymmetric volatility transmission in international stock markets. Journal of International Money and Finance, 14(6), 747-762. http://dx.doi.org/10.1016/0261-5606(95)00031-3

Lanza, A., Manera, M., \& McAleer, M. (2006). Modeling dynamic conditional correlations in WTI oil forward and futures returns. Finance Research Letters, 3(2), 114-132. http://dx.doi.org/10.1016/j.frl.2006.01.005

Lean, H. H., McAleer, M., \& Wong, W. K. (2010). Market efficiency of oil spot and futures: A mean-variance 
and stochastic dominance approach. Energy Economics, 32(5), 979-986. http://dx.doi.org/10.1016/j.eneco.2010.05.001

Lin, W. L., Engle, R. F., \& Ito, T. (1994). Do bulls and bears move across borders? International transmission of stock returns and volatility. Review of Financial Studies, 7(3), 507-537. http://dx.doi.org/10.1093/rfs/7.3.507

Lin, X. S., \& Tamvakis, N. M. (2001). Spillover effects in energy futures markets. Energy Economics, $23(1), 23$. http://dx.doi.org/10.1016/S0140-9883(00)00051-7

Ling, S., \& McAleer, M. (2003). Asymptotic theory for a vector ARMA-GARCH model. Econometric Theory, 19(2), 280-310. http://dx.doi.org/10.1017/S0266466603192092

Liu, Q., \& An, Y. (2011). Information transmission in informationally linked markets: Evidence from US and Chinese commodity futures markets. Journal of International Money and Finance, 30(5), 778-795. http://dx.doi.org/10.1016/j.jimonfin.2011.05.006

Mahalik, K. M., Acharya, D., \& Babu, S. M. (2010). Price discovery and volatility spillovers in futures and spot commodity markets: Some empirical evidence from India. IGIDR Proceedings/Project Reports Series, 06210.

Malik, F., \& Hammoudeh, S. (2007). Shock and volatility transmission in the oil, US and Gulf equity markets. International Review of Economics and Finance, 16(3), 357-368. http://dx.doi.org/10.1016/j.iref.2005.05.005

$\mathrm{Mu}, \mathrm{X}$. (2007). Weather, storage, and natural gas price dynamics: Fundamentals and volatility. Energy Economics, 29(1), 46-63. http://dx.doi.org/10.1016/j.eneco.2006.04.003

Nekhili, R., \& Naeem, M. (2009). Volatility spillovers among the Gulf Arab emerging. The 3rd International Conference on Computational and Financial Econometrics (pp. 1-14). Limassol, Cyprus.

$\mathrm{Ng}$, A. (2000). Volatility spillover effects from Japan and the US to the Pacific-Basin. Journal of International Money and Finance, 19(2), 207-233. http://dx.doi.org/10.1016/S0261-5606(00)00006-1

Ng, K. V., \& Pirrong, C. S. (1996). Price dynamics in refined petroleum spot and futures markets. Journal of Empirical Finance, 2(4), 359-388. http://dx.doi.org/10.1016/0927-5398(95)00014-3

Nomikos, N., \& Andriosopoulos, K. (2012). Modelling energy spot prices: Empirical evidence from NYMEX. Energy Economics, 34(4), 11531169. http://dx.doi.org/10.1016/j.eneco.2011.10.001

Rittler, D. (2012). Price discovery and volatility spillovers in the European Union emissions trading scheme: A high-frequency analysis. Journal of Banking \& Finance, 36(3), 774-785. http://dx.doi.org/10.1016/j.jbankfin.2011.09.009

Sadorsky, P. (2012). Correlations and volatility spillovers between oil prices and the stock prices of clean energy and technology companies. Energy Economics, http://dx.doi.org/10.1016/j.eneco.2011.03.006

Spargoli, F., \& Zagaglia, P. (2007). The comovements between futures markets for crude oil: Evidence from a structural GARCH model. Stockholm University Working Paper 2007-15, 1-19.

Tangerås, P. T. (2012). Optimal transmission regulation of an integrated energy market. Energy Economics, 34(5), 1644-1655. http://dx.doi.org/10.1016/j.eneco.2012.01.007

Tomek, W. G. (1980). Price behavior on a declining terminal market. American Journal of Agricultural Economics, 62(3), 434-445. http://dx.doi.org/10.2307/1240198

Tse, Y. (1999). Price discovery and volatility spillovers in the DJIA index and futures market. Journal of Futures Markets, $19(8)$,

911-930. http://dx.doi.org/10.1002/(SICI)1096-9934(199912)19:8<911::AID-FUT4>3.0.CO;2-Q

Tse, Y., \& Booth, G. G. (1997). Information shares in international oil futures. International Review of Economics and Finance, 6(1), 49-56. http://dx.doi.org/10.1016/S1059-0560(97)90013-7

Zhong, M., Darrat, F. A., \& Otero, R. (2004). Price discovery and volatility spillovers in index futures markets: Some evidence from Mexico. Journal of Banking and Finance, 28(12), 3037-3054. http://dx.doi.org/10.1016/j.jbankfin.2004.05.001

Zivot, E., \& Andrews, D. W. (1992). Further evidence on the great crash, the oil price shock, and the unit-root hypothesis. Journal of Business Economics and Statistics, 10(3), 251-270. 


\section{Notes}

Note 1. American Petroleum Institute (API) gravity index is a measure of how light or heavy a petroleum product relative to water. See Kaufmann and Ullman (2009) for more details.

Note 2. For further details, Chan et al, (1991) could be a good reference on the need to study the volatility spillovers.

Note 3. Previous day observation is used in case of missing observations assuming that the data were unavailable because of national holidays or any other reasons. Two days rolling average to account for time synchronization of different markets lying in different time zones has not been considered in this study due to severe autocorrelation problem as highlighted by (Chiang et al, 2007).

Note 4. Sample oil prices series have been calculated using the first difference of the log price series multiplied by 100 .

Note 5. We have also checked the presence of any structural break in the sample series of oil prices by applying Zivot and Andrews (1992) test of unit root with structural break. We find that all the structural breaks occur in the month of September, 2008, indicating the turmoil in oil prices due to global fiancial crisis. We have also reconfirmed the results of price disovery under regime shifts by emplying Gregory and Hansen (1996) model of cointergation with regime shifts. The results confirm the price discovery results of Johansen and Juselius (1992) for all sample commodities. In order to conserve, we have not mentioned the results. However, results are available with the authors upon request.

\section{Appendix}

Appendix 1. Zivot-Andrew structural breaks unit root results

\begin{tabular}{lll}
\hline Variables & At level & Break period \\
\hline ICE & -4.347 & $23-09-2008$ \\
NYMEX & -4.818 & $23-09-2008$ \\
MCX & -4.256 & $01-09-2008$ \\
MCXSPOT & -4.377 & $01-09-2008$ \\
SPOT & -4.878 & $23-09-2008$ \\
\hline Critical Values & & \\
\hline $1 \%$ & -5.57 & \\
$5 \%$ & -5.08 & \\
\hline
\end{tabular}

Note: All series exhibit non-stationarity, confirming the use of cointegration with regime shifts.

Appendix 2. Gregory and Hansen cointegration test with regime shifts

\begin{tabular}{lll}
\hline Variables & t-stat & Break-Period \\
\hline ICE on SPOT & $-15.830^{* *}$ & $02-02-2009$ \\
SPOT on ICE & $-15.918^{* *}$ & $02-02-2009$ \\
NYMEX on SPOT & $-16.805^{* *}$ & $16-01-2009$ \\
SPOT on NYMEX & $-16.857^{* *}$ & $16-01-2009$ \\
MCX on MCXSPOT & $-20.664^{* *}$ & $04-02-2008$ \\
SPOTMCX on MCX & $-20.497^{* *}$ & $04-02-2008$ \\
ICE on NYMEX & $-39.416^{* *}$ & $21-01-2009$ \\
NYMEX on ICE & $-39.432^{* *}$ & $21-01-2009$ \\
ICE on MCX & $-12.933^{* *}$ & $27-02-2009$ \\
MCX on ICE & $-12.895^{* *}$ & $27-02-2009$ \\
MCX on NYMEX & $-20.029^{* *}$ & $20-02-2009$ \\
NYMEX on MCX & $-20.024^{* *}$ & $20-02-2009$ \\
\hline Significance level critical values & & \\
\hline $1 \%$ & -5.47 & \\
$5 \%$ & -4.95 & \\
\hline
\end{tabular}

Note: ** indicates the level of significance at $1 \%$. EG based GH test considers dependent and independent variable like linear regression. 